\title{
LONGITUDINAL STUDY OF THE VOCATIONAL AND HIGH SCHOOL GRADUATION RATE FROM 2011 TO 2016 IN ERIE COUNTY, NEW YORK
}

\author{
Ilhamdaniah Saleh \\ Faculty of Technology and Vocational Education, Universitas Pendidikan Indonesia, Indonesia \\ School of Architecture and Planning, University at Buffalo, The State University of New York, United States \\ E-mail: ilhamdaniah@upi.edu
}

\begin{abstract}
This study highlighted the discrepancies of education outcomes in urban-suburban settings and the differences between the graduates of vocational high schools and general high schools from 2011 to 2016 in Erie County, New York State, United States. Erie was infamous for racial segregation and the discrepancy of school quality between urban, suburban, and rural areas. New York State Department of Education has invested efforts to improve the education outcomes of vocational and high school education in the region. However, the education outcome gap still existed between those schools. The data source was derived from the School Report Card from 2011 to 2016 published by New York State Department of Education. The outcome variable was the percentage of high school graduates who attained Regent diploma (New York State standard) or the graduation rate. Methods utilized were an independent sample t-test, an analysis of variance, and a hierarchical linear model to measure the difference in longitudinal growth of graduation rate from 2011 to 2016. The results showed that there was a significant difference in the means of the graduation rate between vocational and general high schools. Teacher academic qualifications and certifications had a positive relationship with the graduation rate. The implication of this study called for tremendous efforts to improve the educational outcome, leverage teacher competencies, and close the gap.
\end{abstract}

Keywords: education outcome, graduation rate, teacher competencies, urban-suburban discrepancy, vocational high schools

\section{INTRODUCTION}

Inequity in education access, quality, and outcomes across geographical space are among common problems in the field of education in the United States (US) cities. Erie County, located at western part of New York State, is infamous for its racially and economically segregated metropolitan area [1], [2] as well as inequity in access to quality education across its urban categories [3]. The salient issue is that the discrepancy in education quality exists between urban, suburban, and rural areas. Suburban neighborhoods have schools with more financial resources, higher quality of education facilities, and higher education outcomes.

Despite the efforts to close the discrepancy among regions, the education quality gap also exists between vocational and general high schools. Efforts to leverage education quality and outcomes have been implemented in federal, state, and local scopes for all education levels. The federal government and State Department of Education have implemented policies to improve the quality of vocational education and high school education in general. Specifically, efforts have been intensified in the field of vocational education by implementing the Perkin Act policy to boost the quality of vocational education delivery, teacher quality, and its graduation quality. How well the impact of the policy and actions impacting the graduate quality still need to be examined.

Little research had been conducted to evaluate the contribution of teacher academic qualifications and certifications to education outcomes in the context of Career and Technology Education (CTE) or Technical and Vocational Education and Training (TVET). This is a gap this study aims to bridge. Current research showed that teacher qualification and personal development affect students' achievement in elementary education [4]. Improving teacher's competencies and qualification could be done through teachers continuing education and teacher's certification. Policymakers have focused on increasing 
teacher quality in K-12 (elementary, middle, and high school) education, but minor attention was given to how well vocational or CTE teachers are prepared in the US [5].

The teacher factor is among the utmost important factors in determining educational outcomes, in addition to student socioeconomic, school variables, and neighborhood factors. Teacher factors that contribute to education outcomes are teachers' academic qualifications and certifications. In the case of vocational education, TVET teacher professional development is among the factors to leverage the quality of TVET education [6]. For vocational teachers in the US, the US Department of Education also pays attention to prepare the academic qualifications for future vocational teachers [7]. For vocational field, competency standard for TVET teacher is regulated and become increasing importance across the globe including in ASEAN countries [8].

Having that said, this study focuses on inequity problems in secondary school level in the study area, especially between vocational and general high schools. Among the problems addressed in this study are (1) there is a discrepancy in high school education outcomes between urban, suburban, and rural high schools, (2) there is a discrepancy in the graduation rate between vocational high schools and general high schools, (3) there is a need for assessment of the impact of improvement in teacher competencies over the past years from 2011 to 2016 to close the gap.

This study advances from prior literature by measuring the discrepancy between schools using longitudinal dataset. The contribution of this study to the current body of literature is in the way that growth trajectory of high schools is broken down into vocational and general high schools. The proposed approach using a multilevel model to measure the growth trajectory by adding teacher competency variable also differentiates this study.
The objectives of this paper are (1) to measure the discrepancy in education outcomes between urban, suburban, and rural areas in Erie County, (2) to measure the difference between the graduation rate of vocational high schools and general high schools from 2011 to 2016, and (3) to measure the relationship between teachers' competency factors (teacher academic qualification and teacher certification) with the growth trajectory of vocational and general high school graduation rates.

The research questions of this study are (1) is there any significant difference between the graduation rate in urban, suburban, and rural areas in Erie County?, (2) is there any significant difference between the graduation rate of vocational high schools and general high schools from 2011 to 2016?, (3) how does the growth trajectory differ between vocational and general high schools?, and (4) does the improvement in teachers' competency from 2011 to 2016 have a significant impact on the growth trajectory of vocational and high school graduation rates in Erie County?

\section{METHOD}

This study is quantitative research using secondary data. The data source was from School Report Card from the academic year 2010-2011 to 2015-2016 derived from New York State Department of Education [9]. The case study area was Erie County, New York presented in Figure 1. This study categorized the high schools based on their location and the type of high schools. Based on the location, there are urban, suburban (inner- and outersuburban), and rural high schools. Suburban areas are bordering urban Buffalo, while rural areas are located at the outskirt of Erie County. Based on the type of high schools, there are general high schools and vocational high schools. Vocational high schools (VOC-HS) are mostly located in the urban area, in the downtown of the city of Buffalo (see Table 1). 


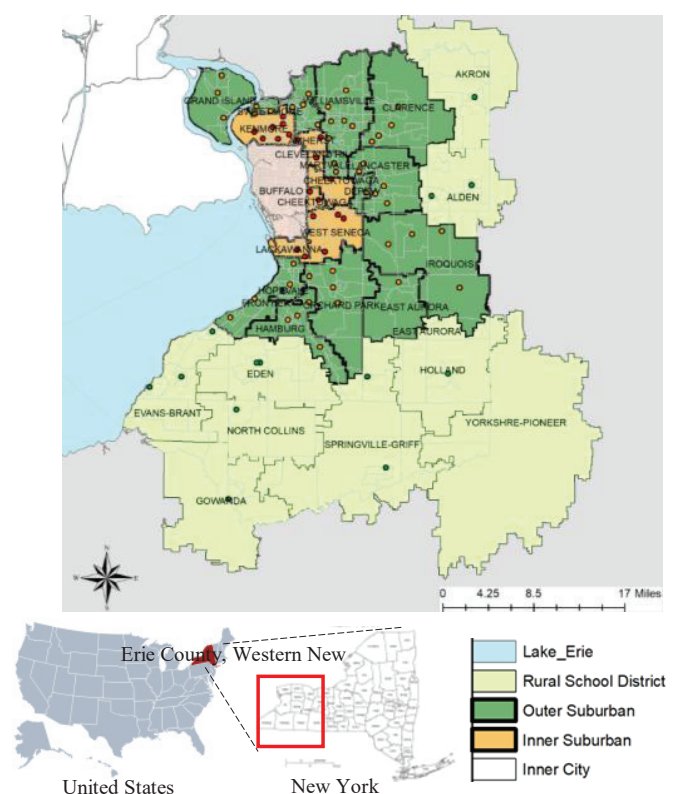

Figure 1. Erie County's Urban, Suburban, and Rural Setting in Western New York, United States

There is a stark contrast of neighborhood quality between the urban and suburban area in the Buffalo Metropolitan area. Inner city and its suburban counterparts are highly racially and socio-economically segregated. Downtown urban area of Buffalo is inhabited by disproportionately Black and immigrants with lower socio-economic status and low quality of schools. This is the place where vocational high schools are located in this study area. Therefore, vocational high schools serve students of the lower socioeconomic background and have lower school quality.

Table 1. High School Spatial Distribution

\begin{tabular}{ccc}
\hline Category & $\begin{array}{c}\text { Vocational } \\
\text { High School }\end{array}$ & $\begin{array}{c}\text { General } \\
\text { High School }\end{array}$ \\
\hline Urban & 15 & 8 \\
Inner Suburban & 0 & 11 \\
Outer Suburban & 0 & 15 \\
Rural & 0 & 7 \\
Total & 15 & 41 \\
\hline
\end{tabular}

The outcome variable was the percentage of high school graduates who attained Regent diploma (New York State standard), furthermore referred as graduation rate. Since this is a longitudinal study, time is an independent variable indicating the repeated measurement. The independent variables were teacher competency and academic qualification. Teacher competency in this study was measured by the percentage of teachers without teaching certification. Teachers' academic qualification was measured by the percentage of teachers attaining graduate degrees (master or doctoral degree). The dummy variable of vocational status and urban location were also included as independent variables. The description of variables of this study is depicted in Table 2.

Data analysis method in this study comprised of descriptive statistics, an analysis of variance (ANOVA), an independent sample t-test, and a Hierarchical Linear Model (HLM). ANOVA was used to measure the difference of the means of percentage of Regent diploma attainment (per_reg_dipl) or graduation rate among urban, suburban, and rural high schools. The independent sample T-test was used to compare the graduation rate of vocational high schools and general high schools.

The reason for using HLM in this study was to take account of the hierarchically organized data in an education setting and longitudinal data measured in multiple years. The utilization of HLM can avoid the inflation of Type I statistical error ad variance if ordinary regression analysis is used to analyze hierarchically structured data. This can minimize the errors in interpreting the results of the statistical significance test.

Hierarchically organized data is common in the education research setting. It can take various types of multilevel form: (1) number of level, for example, students nested within school (2-level), students nested within schools and schools nested within school districts (3level); (2) type of design: cross-sectional in one period of time, growth data of individual student, or growth data of schools with repeated yearly measurement nested within a school (2level) [10]. Data in a similar group will have a high correlation with each other. Thus it will have high co linearity. Multilevel models have been developed to take into account the hierarchical structure, nesting of the data, and co linearity between data within the similar 
group [11]. Growth data can be analyzed using multilevel or mixed-model approach, also known as a hierarchical linear model [12]. The growth data of educational outcomes that are nested within a group (school) calls for a multilevel model.

The Hierarchical Linear Model was used to measure: (1) variability of graduation rate between-schools, (2) the shape of longitudinal growth trajectory across years, and (3) factors impacting the longitudinal growth of graduation rate of high schools. By adding the dummy variable of the urban category, HLM can explain the difference in the graduation rate among urban categories (urban, suburban, or rural). Adding a dummy variable of school types could explain the difference in the graduation rate between vocational high schools and general high schools. There was a multilevel structure in modeling the data in this study. Level-1 was multiple measurements of graduation rate in 2011, 2012, 2013, 2014, 2015, and 2015. Measurement in 2011 was coded time $=0$, as the initial year. Measurement in 2012, 2013, 2014, 2015, and 2016 were coded as time $=1$, time $=2$, time $=3$, time $=4$, and time $=5$. Level- 2 was school, where the repeated measurements in several years were nested within the school. The summary of the HLM model building process is depicted in Table 3 . Model 1 was a model with no predictor to measure several variances in the model, namely variance within-schools (level-1) and variance between-schools (level-2), by calculating the Intra-Class Correlation (ICC).

Table 2. Variable Description

\begin{tabular}{|c|c|c|c|c|}
\hline Variable name & Level & Description & Values & Measureme \\
\hline Entity_ID & School & $\begin{array}{l}\text { School identifier, a unique number } \\
\text { assigned by NYSED }\end{array}$ & $\begin{array}{l}12 \text { digit number } \\
\text { uniquely assigned for } \\
\text { each school in NYS }\end{array}$ & $\begin{array}{l}\text { Nominal } \\
\text { (numeric) }\end{array}$ \\
\hline Entity_Name & School & School name & School name & $\begin{array}{l}\text { Nominal } \\
\text { (string) }\end{array}$ \\
\hline Schooldistrict & $\begin{array}{l}\text { School } \\
\text { district }\end{array}$ & School district name & School district name & $\begin{array}{l}\text { Nominal } \\
\text { (string) }\end{array}$ \\
\hline Year & $\begin{array}{l}\text { Within } \\
\text { school }\end{array}$ & Year of measurement & $\begin{array}{l}2011,2012,2013,2014, \\
2015,2016\end{array}$ & \\
\hline Time & $\begin{array}{l}\text { Within } \\
\text { school }\end{array}$ & $\begin{array}{l}\text { Variable representing six linear } \\
\text { occasions in time, measuring school } \\
\text { graduation rate. }\end{array}$ & $\begin{array}{l}0=2011 \text { measurement } \\
1=2012 \text { measurement } \\
2=2013 \text { measurement } \\
3=2014 \text { measurement } \\
4=2015 \text { measurement } \\
5=2016 \text { measurement }\end{array}$ & $\begin{array}{l}\text { Scale } \\
\text { (numeric) }\end{array}$ \\
\hline Per_Reg_dipl & $\begin{array}{l}\text { Within } \\
\text { school }\end{array}$ & $\begin{array}{l}\text { A dependent variable represents the } \\
\text { percentage of high school graduates } \\
\text { attaining Regents diploma. This } \\
\text { variable is also called the graduation } \\
\text { rate in this study. }\end{array}$ & $0 \%$ to $100 \%$ & $\begin{array}{l}\text { Scale } \\
\text { (numeric) }\end{array}$ \\
\hline UrbanCategory & School & $\begin{array}{l}\text { A variable representing whether a } \\
\text { high school is located in urban, } \\
\text { inner suburban, outer suburban, or } \\
\text { rural area }\end{array}$ & $\begin{array}{l}1=\text { urban school } \\
2=\text { inner suburban } \\
\text { school } \\
3=\text { outer suburban }\end{array}$ & $\begin{array}{l}\text { Nominal } \\
\text { (numeric) }\end{array}$ \\
\hline Voc_dummy & School & $\begin{array}{l}\text { Dummy variable representing } \\
\text { whether a high school is a } \\
\text { vocational high school or general }\end{array}$ & $\begin{array}{l}0=\text { vocational high } \\
\text { school } \\
1=\text { general high school }\end{array}$ & $\begin{array}{l}\text { Nominal } \\
\text { (numeric) }\end{array}$ \\
\hline $\begin{array}{l}\text { Chg_per_outcert_ } \\
1116\end{array}$ & School & $\begin{array}{l}\text { Independent variable representing } \\
\text { the change from } 2011 \text { to } 2016 \text { in the } \\
\text { percentage of the teacher without } \\
\text { valid certification }\end{array}$ & $0 \%$ to $100 \%$ & $\begin{array}{l}\text { Scale } \\
\text { (numeric) }\end{array}$ \\
\hline $\begin{array}{l}\text { Chg_per_mastplus } \\
1116\end{array}$ & School & $\begin{array}{l}\text { Independent variable representing } \\
\text { the change from } 2011 \text { to } 2016 \text { in the } \\
\text { percentage of the teacher with } \\
\text { academic qualification of Master }\end{array}$ & $0 \%$ to $100 \%$ & $\begin{array}{l}\text { Scale } \\
\text { (numeric) }\end{array}$ \\
\hline
\end{tabular}


Table 3. Summary of the HLM Model Building Process

\begin{tabular}{|c|c|c|c|}
\hline Model 1 & Model 2 & Model 3 & Model 4, 5, 6, 7 \\
\hline $\begin{array}{l}\text { No predictors, just } \\
\text { random effect of the } \\
\text { intercept }\end{array}$ & $\begin{array}{l}\text { Model } 1+\text { level-1 } \\
\text { fixed effects }\end{array}$ & $\begin{array}{l}\text { Model } 2+\text { random slopes for level- } \\
1 \text { predictors }\end{array}$ & $\begin{array}{l}\text { Model } 3+\text { level-2 fixed } \\
\text { effects }\end{array}$ \\
\hline $\begin{array}{l}\text { Output used to calculate } \\
\text { Intra-class Correlation } \\
\text { (ICC). It provides } \\
\text { information of how } \\
\text { much variation in the } \\
\text { outcome exists between } \\
\text { level-2 units. }\end{array}$ & $\begin{array}{l}\text { Results indicate the } \\
\text { relationship between } \\
\text { level-1 predictors and } \\
\text { the outcome variable } \\
\text { (the graduation rate). } \\
\text { Level-1 predictor in }\end{array}$ & $\begin{array}{l}\text { Fixed effect results } \\
\text { provide the same information as } \\
\text { Model 2; provide information about } \\
\text { the relationship between level-1 } \\
\text { predictors (time) and the outcome } \\
\text { variable (school graduation rate). }\end{array}$ & $\begin{array}{l}\text { Level-2 fixed effect } \\
\text { results indicate the } \\
\text { relationship between level-2 } \\
\text { predictors and the outcome } \\
\text { variable (graduation rate). } \\
\text { Level-2 predictor in Model 4: } \\
\text { dummy urban category; }\end{array}$ \\
\hline $\begin{array}{l}\text { More specifically, how } \\
\text { much variation in the } \\
\text { high school graduation } \\
\text { rate between-schools. }\end{array}$ & $\begin{array}{l}\text { Model 2: time and in } \\
\text { Model 3: } \\
\text { time_squared. }\end{array}$ & $\begin{array}{l}\text { Random slope results } \\
\text { reveal if the relationships between } \\
\text { level-1 predictor (time and } \\
\text { time_squared) and the outcome } \\
\text { variable (graduation rate) vary } \\
\text { between level-2 units (schools). }\end{array}$ & $\begin{array}{l}\text { Model 5: dummy vocational } \\
\text { school; Model 6: teacher } \\
\text { certification, and Model 7: } \\
\text { teacher academic } \\
\text { competency) }\end{array}$ \\
\hline
\end{tabular}

Model 2 incorporated time as a level-1 covariate. Model 2 was also a level-1 model that accurately reflects the shape of the growth trajectory over time by incorporating the time as a fixed-effect level-1 covariate. Model 3 measured whether the relationship between time with the graduation rate varied across schools (level-2) by incorporating time as a fixed-effect and random-effect in the model. Model 4 adds level-2 predictors: urban_category, to measure the difference of growth trajectory among schools in an urban, inner-suburban, outer-suburban, and rural area. Model 5 added level-2 predictors: voc_dummy, to measure whether there was a difference in graduation rates if a school is categorized as vocational high school (voc_dummy=0) or general high school (voc_dummy=1). Model 6 added level-2 predictors: the change in the percentage of teacher certification (Chg_per_outcert_1116) and the change in the percentage of teacher academic qualification (Chg_per_mastplus_1116) to measure the impact of the change in teacher certifications and the change in teacher academic qualifications on the graduation rate from 2011 to 2016.

The equation of the level-1 model (repeated measurements) without the timerelated variable:

$$
\mathrm{Y}_{t i}=\pi_{o i}+\varepsilon_{t i}
$$

where $\mathrm{Y}_{t i}$ is the dependent variable, $\pi_{o i}$ is the average means of graduation rate across six measurements (2011 to 2016), and $\varepsilon_{t i}$ represents an error in predicting the average graduation rate for schools. The equation of the level-2 model, between schools, the average growth across occasions is described as:

$$
\pi_{o i}=\beta_{00}+u_{o i}
$$

where $\beta_{00}$ is the intercept describing the average initial status mean between schools, and $u_{o i}$ is the level-2 random component associated with describing differences in average graduation rate between schools. Substituting equation (2) into equation (1) resulted in the following combined equation:

$$
\mathrm{Y}_{t i}=\beta_{00}+u_{o i}+\varepsilon_{t i}
$$

\section{RESULTS AND DISCUSSION}

The result of descriptive statistics is reported in Table 4. The table shows the number of high schools in each urban category and the means of graduation rate for each urban category.

Table 4. Descriptive statistics

\begin{tabular}{crrrr}
\hline $\begin{array}{c}\text { Urban } \\
\text { category }\end{array}$ & Schools & $\begin{array}{c}\text { Observa } \\
\text { tions }\end{array}$ & Mean & SD \\
\hline Urban & 23 & 12 & 82.65 & 17.85 \\
Inner & 11 & 63 & 93.16 & 8.28 \\
Outer & 15 & 90 & 96.83 & 1.89 \\
Rural & 7 & 42 & 95.74 & 3.69 \\
\hline
\end{tabular}


The tabulation of comparison of means between vocational (voc-HS) and general high school (HS) graduation rates in various location categories are depicted in Table 5. Suburban and rural areas have the highest means of graduation rate compared to the urban category. This is related to the fact that suburban neighborhoods in the US are the most affluent neighborhoods.

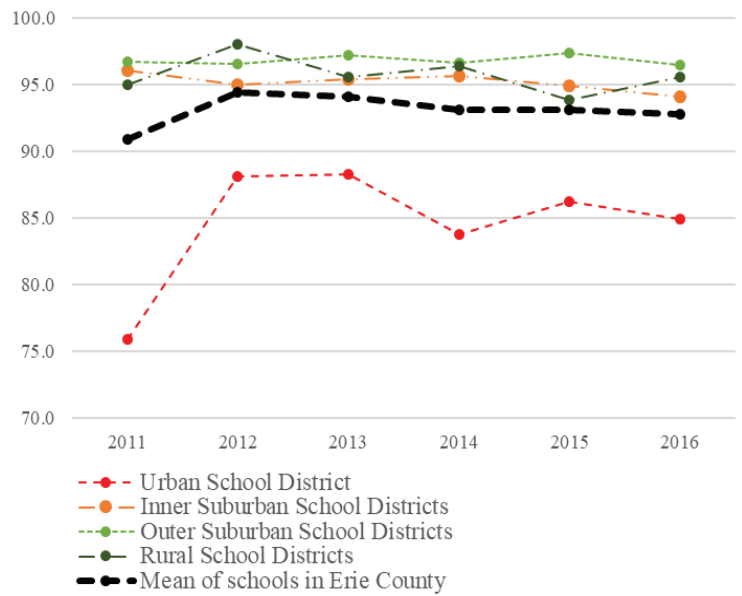

Figure 2. Comparison of Means of Percentage of Regents Diploma Attainment among Urban, Inner Suburban, Outer Suburban, and Rural High Schools from 2011 to 2016

Table 5. Comparison of Means of Vocational and General High School Graduation Rates from 2011 to 2016

\begin{tabular}{ccccccc}
\hline Tim & Year & $\begin{array}{c}\text { Vocation } \\
\text { al }\end{array}$ & \multicolumn{3}{c}{ General High School } \\
\cline { 5 - 7 } & & School & Urban & \multicolumn{2}{c}{$\begin{array}{c}\text { Subur } \\
\text { ban }\end{array}$} & Rural \\
\hline 1 & 2011 & 78.0 & 71.5 & 96.4 & 95.0 \\
2 & 2012 & 88.1 & 88.3 & 95.8 & 98.0 \\
3 & 2013 & 90.6 & 83.7 & 96.3 & 95.6 \\
4 & 2014 & 86.3 & 79.4 & 96.2 & 96.4 \\
5 & 2015 & 86.6 & 85.5 & 96.1 & 93.9 \\
6 & 2016 & 86.1 & 83.0 & 95.3 & 95.6 \\
2011 to 2016 & 86.0 & 81.9 & 96.0 & 95.8 \\
\hline
\end{tabular}

The comparison between the means of the graduation rate of voc-HS and that of HS in Erie County is depicted in Figure 3. The data tabulation showed that the means of the graduation rate of vocational high schools is lower than that of general high schools. This tabulation of means is further tested using means comparison by t-test analysis.

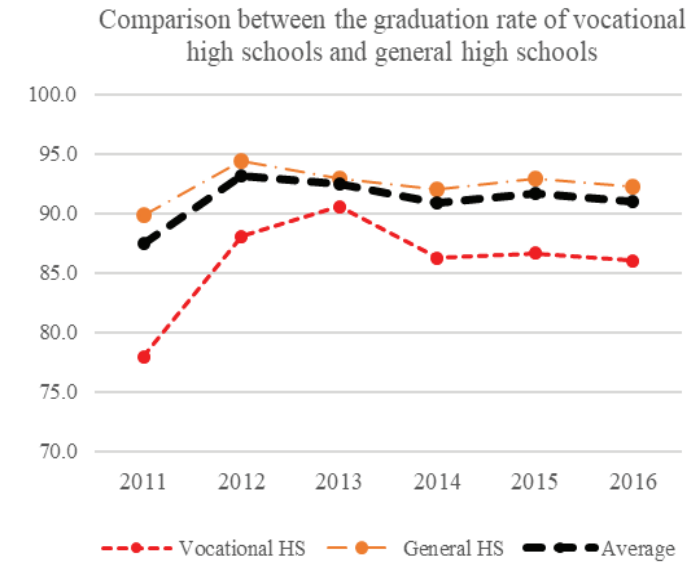

Figure 3. Comparison of Means of the Graduation Rate between Vocational and General High Schools

Note that in the academic year of 2013 to 2014 , there is a slight slump in the graduation rate. It is the effect of the new Common Core Standard being implemented throughout New York State schools. Starting from that academic year, the more rigorous academic standard was implemented, resulted in some decline in educational outcomes in all education levels.

Results of ANOVA among urban, suburban, and rural high school's graduation rate. There were significant differences in the pairwise comparison between urban vs. suburban, urban vs. rural. However, there was no significant difference in pairwise comparison between suburban vs. rural high schools from 2011 to 2016.

The result of the T-test to compare the graduation rate of vocational high schools and general high schools show that there is a significant difference in the means of graduation rate between vocational and general high schools from 2011 to 2016 . The results of HLM to measure the longitudinal growth of graduation rate of vocational high schools and general high schools from 2011 to 2016 is explained by explaining the results of serials of HLM model (Table 7). The value of the dependent variable was predicted by serial of models, from Model 1 to Model 7. Model 1 with no predictor allowed the calculation of 
intra-class correlation (ICC) for the unconditional growth curve model. This was done by calculating the ratio of the intercept variance to total variance (intercept+residual).

Table 6. Model 1 Result: Covariance Parameter Estimate

\begin{tabular}{cccrc}
\hline Cov & Subject & Esti- & \multicolumn{1}{c}{ Std. } & Pr $>\mathrm{Z}$ \\
Parm & & mate & Erro & \\
\hline Intercept & ENTITY_NAME & 118.37 & 4.76 & $<.0001$ \\
Residual & & 70.90 & 11.43 & $<.0001$ \\
\hline
\end{tabular}

$\mathrm{ICC}=118.37 /(118.37+70.90)=0.625$

Thus, $62.5 \%$ of the variance in graduation rate exist between-schools. This high percentage of variability between schools justified the utilization of hierarchical linear model in this study as opposed to using ordinary least square (OLS) regression which ignored the hierarchical structure of the data.

In model 2, Time was insertedtime as a covariate in the equation. In this study, the growth trajectory is modeled as a linear growth. The negative estimate sign means schools have negative growth over time, the graduation rate declines over time, especially since 2013. This adheres to the graduation rate trajectory in
Figure 3. However, the result shows time is not statistically significant. This indicates that schools are changing at the same rate (same growth trajectory) from 2011 to 2016, but have a different starting point.

Based on visual observation of growth curve, the growth trajectory as a quadratic curve was also modeled. Therefore, this study also incorporated time_squared as a covariate to measure the change in the rate of change of the graduation rate growth in Model 3. The results showed that the rate change of schools from 2011 to 2016 reis not the same (linear) but having a quadratic growth shape, with a peak in 2013.

Model 4 showed that Urban_category is a significant variable. The urban school group is dummy coded as zero. That means that the intercept is interpreted as the graduation rate for urban schools. Urban schools have lower means of graduation rate. Model 5 results showed that Voc_dummy was a significant variable. Plugging in the value of dummy variable " 0 " for vocational schools to the equation (3) results in the intercept value of vocational schools. Vocational schools had a lower graduation rate compare to that of general high schools.

Table 7. Summary of HLM results

\begin{tabular}{|c|c|c|c|c|c|c|c|}
\hline Parameters & Model 1 & Model 2 & Model 3 & Model 4 & Model 5 & Model 6 & Model 7 \\
\hline Intercept & $\begin{array}{r}89.716 \\
(1.500)^{* * *}\end{array}$ & $\begin{array}{r}90.117 \\
(1.660)^{* *}\end{array}$ & $\begin{array}{r}88.688 \\
(1.777)^{* * *}\end{array}$ & $\begin{array}{r}77.713 \\
(2.846)^{* * *}\end{array}$ & $\begin{array}{r}82.743 \\
(2.756)^{* * *}\end{array}$ & $\begin{array}{r}84.126 \\
(2.643)^{* * * *}\end{array}$ & $\begin{array}{r}83.996 \\
(2.705)^{* * *}\end{array}$ \\
\hline \multicolumn{8}{|l|}{ Fixed effect } \\
\hline $\begin{array}{l}\text { Level } 1 \text { predictor: } \\
\text { Time } \\
\text { Time_squared }\end{array}$ & - & $\begin{array}{r}-0.155 \\
(0.580) \\
-\end{array}$ & $\begin{array}{r}1.937 \\
(0.993) \\
-0.413 \\
(0.188)^{*}\end{array}$ & $\begin{array}{r}1.776 \\
(0.799)^{*} \\
-0.389 \\
(0.166)^{*}\end{array}$ & $\begin{array}{r}1.779 \\
(0.286)^{*} \\
-0.387 \\
(0.166)^{*}\end{array}$ & $\begin{array}{r}1.758 \\
(0.804)^{*} \\
-0.387 \\
(0.167)^{*}\end{array}$ & $\begin{array}{r}1.762 \\
(0.800)^{*} \\
-0.385 \\
(0.166)^{*}\end{array}$ \\
\hline $\begin{array}{l}\text { Level } 2 \text { predictor: } \\
\text { UrbanCategory }\end{array}$ & - & - & - & $\begin{array}{r}5.325 \\
(0.998)^{* * *}\end{array}$ & - & - & - \\
\hline Voc_dummy & - & - & - & - & $\begin{array}{r}8.033 \\
(3.029)^{*}\end{array}$ & $\begin{array}{r}6.329 \\
(2.915)^{*}\end{array}$ & $\begin{array}{r}6.467 \\
(2.998)^{*}\end{array}$ \\
\hline Chg_per_outcert_1116 & - & - & - & - & & $\begin{array}{r}-0.660 \\
(0.263)^{*}\end{array}$ & - \\
\hline $\begin{array}{l}\text { Chg_per_permastplus_ } 1 \\
116\end{array}$ & - & - & - & - & - & - & $\begin{array}{r}-0.662 \\
(0.280)^{*}\end{array}$ \\
\hline$\frac{\text { Random effect }}{\text { Time_squared }}$ & - & - & yes & yes & yes & yes & yes \\
\hline \multicolumn{8}{|l|}{ Model fit } \\
\hline -2 Log Likelihood & 2420.5 & 2420.2 & 2415.4 & 2334.8 & 2351.5 & 2345.7 & 2346.1 \\
\hline AIC (smaller is better) & 2426.5 & 2428.2 & 2425.4 & 2348.8 & 2365.5 & 2361.7 & 2362.1 \\
\hline
\end{tabular}

Estimate of the coefficient (Standard Error)

* Statistically significant $\mathrm{p}<0.05, * *$ Statistically significant $\mathrm{p}<0.01, * * *$ Statistically significant $\mathrm{p}<0.001$ 
The results of Model 6 showed that type of school and teacher factors (Chg_per_outcert_1116) are significant factors impacting graduation rate. For a school with an average change of teacher competency, the graduation rate is 84.126 .

In model 7 , the variable of vocational school and teacher academic qualification (Chg_per_permastplus_1116) were significant factors impacting graduation rate. For a school with an average change of teacher qualification, the graduation rate is 83.996. This means that the percentage of teachers with good academic qualifications is positively affecting the graduation rate.

Adding more covariates in Model 4, 5, 6, 7 improves the model fit, shown by the decreased value of -2 Log Likelihood and AIC compared to the initial model. The means of the graduation rate of the CTE schools is significantly lower than the means of the graduation rate of general high schools. Its value is affected by the percentage of teachers without certification. The negative sign of the coefficient means the graduate rate is negatively related to the percentage of the teacher without certification.

This study confirmed other studies which indicate that teacher academic qualifications and certification are important factors affecting educational outcomes. This study confirmed with other academic longitudinal studies with significant time variable. The longitudinal growth trajectory from 2011 to 2016 was quadratic, with one peak in 2013. This is related to the implementation of a more rigorous academic standard of Common Core. A significant variance estimate of time_squared means schools did not change at the same rate [10].

\section{CONCLUSION}

In conclusion, the multilevel model for change showed its ability to model the growth trajectory of graduation rates from 2011 to
2016. It also highlighted the discrepancy between urban categories and the gap between vocational and general high schools' graduation rate. The HLM method was successful in measuring the variability between schools, and illustrated the growth difference among urban category, differentiated the growth between vocational and regular high schools. Improved teacher competencies positively affect the graduation rate. The increasing percentage of teachers with certificates positively contributed to the improvement of the graduation rate of HS and voc-HS. More teachers attaining master and doctoral level education also positively contributed to graduation rate improvement over the years.

Theoretical implication of this study was that adding time-variant independent variables into the multilevel model equation will help to understand the systematic change over time and how the change in independent variables over time impact the change of dependent variable over time [13]. Especially, the relationship between the growth in teacher competencies with the growth trajectory of graduation rate.

The results of this study had policy implications. The regional education outcome gap between urban, suburban, and rural area calls for concerted efforts in education planning and urban planning sectors. This study also has implications in education policy, calling for improvement in teacher competencies to leverage education quality and school outcomes, especially voc-HS. In the case of CTE policy, improving teacher certification and academic qualifications will have a significant improvement on the vocational graduation rate.

Despite current efforts, there was still a gap in graduation rate between vocational schools and general high schools. This is worthy of attention from education policymakers, namely the NYS Department of Education. This has managerial implications in vocational schools and NYS education department. Systematic effort to leverage teacher academic qualification in the current 
Perkin Act is important to close the gap. The result of this study also calls for further studies to deepen our understanding of the impact of vocational teacher competencies in different areas of vocational high schools' expertise. Occupational experience is an important factor on top of academic qualifications and certification for CTE teachers. Therefore, this aspect of teacher quality improvement is also important and deemed necessary to be studied further.

\section{REFERENCES}

[1] C. D. Rogers, "Poverty Analysis Using Alternative Poverty Measures and Geospatial Technology in the BuffaloNiagara Falls, New York, Metropolitan Statistical Area: 1970-2000," URISA J., vol. 26, no. 2, pp. 51-59, 2014.

[2] L. Yin, "The Dynamics of Residential Segregation in Buffalo: An Agent-based Simulation," Urban Stud., vol. 46, no. 13, pp. 2749-2770, 2009.

[3] M. Pasciak, "How hard is it to get into the Buffalo school you want," Buffalo News, 2011.

[4] K. Suk Yoon, T. Duncan, S. Wen-Yu Lee, B. Scarloss, and K. L. Shapley, "Reviewing the evidence on how teacher professional development af fects student achievement R E L 200 7-N o. 03 3," Washington, DC, 2007.

[5] H. R. D. Gordon, "Career and Technical Education Instructional Programs and Teachers," in The History and Growth of Career and Technical Education in America, 4 ed., Vol. 4., Illinois: Waveland Press Inc., 2014, p. 487.
[6] I. W. Djatmiko, "A Study on the Empowering Teachers' Professional Development and Quality Assurance to Increase Teachers' Effectiveness in Vocational Secondary Schools," $J$. Pendidik. Teknol. dan Kejuru., vol. 23, no. 2, pp. 144-151, 2016.

[7] K. Cramer, "The Vocational Teacher Pipeline: How Academically Well Prepared is the Next Generation of Vocational Teachers?," Washington DC, 2004.

[8] M. Grosch, "Developing a Competency Standard for TVET Teacher Education in Asean Countries," J. Pendidik. Teknol. dan Kejuru., vol. 23, no. 3, pp. 279-287, 2017.

[9] New York State Education Department, "School Report Card.," 2017.

[10] B. A. Bell, M. Ene, W. Smiley, and J. A. Schoeneberger, "A Multilevel Model Primer Using SAS PROC MIXED," in the SAS Global Forum, 2013.

[11] R. H. Heck and S. L. Thomas, An introduction to multilevel modeling techniques: MLM and SEM Approaches Using Mplus. New York: Taylor and Francis, 2015.

[12] S. W. Raudenbush and A. S. Bryk, Hierarchical Linear Models: Applications and Data Analysis Methods. New York: Sage Publications, 2002.

[13] D. B. McCoach and B. Kaniskan, "Using Time-Varying Covariates in Multilevel Growth Models. Frontier in Psychology," Front. Psychol., vol. 1, no. 17, pp. 1-17, Jun. 2010. 